\title{
Evidence of meltwater retention within the Greenland ice sheet
}

\author{
A. K. Rennermalm ${ }^{1}$, L. C. Smith ${ }^{2}$, V. W. Chu ${ }^{2}$, J. E. Box ${ }^{3}$, R. R. Forster ${ }^{4}$, M. R. Van den Broeke ${ }^{5}$, D. Van As ${ }^{3}$, and \\ S. E. Moustafa ${ }^{1}$ \\ ${ }^{1}$ Department of Geography, Rutgers, The State University of New Jersey, New Brunswick, NJ, USA \\ ${ }^{2}$ Department of Geography, University of California Los Angeles, Los Angeles, CA, USA \\ ${ }^{3}$ Geological Survey of Denmark and Greenland (GEUS), Copenhagen, Denmark \\ ${ }^{4}$ Department of Geography, University of Utah, Salt Lake City, UT, USA \\ ${ }^{5}$ Institute for Marine and Atmospheric Research, Utrecht University, Utrecht, the Netherlands
}

Correspondence to: A. K. Rennermalm (asa.rennermalm@rutgers.edu)

Received: 18 May 2012 - Published in The Cryosphere Discuss.: 9 August 2012

Revised: 7 July 2013 - Accepted: 8 July 2013 - Published: 23 September 2013

\begin{abstract}
Greenland ice sheet mass losses have increased in recent decades with more than half of these attributed to surface meltwater runoff. However, the magnitudes of englacial storage, firn retention, internal refreezing and other hydrologic processes that delay or reduce true water export to the global ocean remain less understood, partly due to a scarcity of in situ measurements. Here, ice sheet surface meltwater runoff and proglacial river discharge between 2008 and 2010 near Kangerlussuaq, southwestern Greenland were used to establish sub- and englacial meltwater storage for a small ice sheet watershed $\left(36-64 \mathrm{~km}^{2}\right)$. This watershed lacks significant potential meltwater storage in firn, surface lakes on the ice sheet and in the proglacial area, and receives limited proglacial precipitation. Thus, ice sheet surface runoff not accounted for by river discharge can reasonably be attributed to retention in sub- and englacial storage. Evidence for meltwater storage within the ice sheet includes (1) characteristic dampened daily river discharge amplitudes relative to ice sheet runoff; (2) three cold-season river discharge anomalies at times with limited ice sheet surface melt, demonstrating that meltwater may be retained up to 1-6 months; (3) annual ice sheet watershed runoff is not balanced by river discharge, and while near water budget closure is possible as much as $54 \%$ of melting season ice sheet runoff may not escape to downstream rivers; (4) even the large meltwater retention estimate $(54 \%)$ is equivalent to less than $1 \%$ of the ice sheet volume, which suggests that storage in en- and subglacial cavities and till is plausible. While this study is the first to provide evidence for meltwater retention and delayed release within the Greenland ice sheet, more information is needed to establish how widespread this is along the Greenland ice sheet perimeter.
\end{abstract}

\section{Introduction}

Greenland ice sheet mass losses derive from increased ice discharge and meltwater runoff since the early 1990s (Rignot et al., 2008). Increases in meltwater runoff are estimated to be twice as large as cumulative ice discharge anomalies between 2000 and 2008 (Van den Broeke et al., 2009a). This meltwater loss intensification is consistent with observations of rising mean annual near-surface air temperature $\left(+1.8^{\circ} \mathrm{C}\right.$ since the Little Ice Age; Box et al., 2009) and expanding melt area on the ice sheet surface (Mote, 2007; Tedesco, 2007), including a record near-total surface melting on 12 July 2012 (Hall et al., 2013; Nghiem et al., 2012). Furthermore, declining ice sheet surface albedo amplifies temperature sensitivity, driving half of the runoff increase between 2000 and 2012 (Box et al., 2012).

Continued mass loss from the Greenland ice sheet has the potential to raise global sea levels by $9 \pm 4 \mathrm{~cm}$ by 2050 (Rignot et al., 2011) and between 17 and $54 \mathrm{~cm}$ by 2100 (Pfeffer et al., 2008). These estimates project that $13-58 \%$ of this increased mass loss occurs as a result of declining surface mass balance (Pfeffer, 2008; Rignot et al., 2011). The wide range in this fraction can partly be attributed to uncertainties associated with quantifying the link between surface mass balance and ice dynamics (Bindschadler et al., 2013), and surface meltwater retention (e.g., Rennermalm et al., 2013).

It has long been known that meltwater transport from the ice sheet surface to its margin occurs through a complex, poorly understood system of supra-, en- and subglacial pathways consisting of crevasses, moulins, fractures, conduits and supraglacial stream channels (Fountain and Walder, 1998), referred to as the cryo-hydrologic system (CHS) 
(Phillips et al., 2010, 2013). Meltwater passage through the CHS and temporary storage in englacial cavities, and proglacial and supraglacial lakes, can retard gravity-driven flow of meltwater from its creation on the ice sheet surface to its appearance at the ice margin (Cuffey and Paterson, 2010; Fountain and Walder, 1998). Meltwater can be retained if it refreezes or is accumulated in firn layers (Boggild, 2007; Boggild et al., 2005; Brown et al., 2011; Fausto et al., 2009; Greuell and Konzelmann, 1994; Pfeffer et al., 2008; Reeh, 1991), which may buffer meltwater losses for several decades (Harper et al., 2012), leaving a lesser portion that truly contributes to sea level rise.

Internal glacier water storage can redistribute water losses seasonally by collecting water in the early melting season, and releasing it in the late melting season (Cowton et al., 2012; Jansson et al., 2003) or in winter months (Hagen et al., 2003; Hodson, 2005; Jansson et al., 2003; Stenborg, 1965; Wadham, 2000). In southwestern Greenland, an area with prominent surface meltwater lakes (Selmes et al., 2011), $40 \%$ of lakes store water and freeze up in winter months with remaining lakes either draining slowly (37\%), quickly $(14 \%)$, or its state cannot be determined (8\%) (Selmes et al., 2013). Sudden drainage of ice sheet supra- (Bartholomew et al., 2011; Doyle et al., 2013), en-, sub- (Mathews, 1963), and proglacial meltwater lakes (Mernild and Hasholt, 2009; Russell, 2009; Russell et al., 2011) can result in pronounced river discharge anomalies.

Direct observations of ice sheet meltwater runoff extending over multiple years (Van den Broeke et al., 2011a) and ice sheet runoff losses through river discharge are scarce for Greenland (Ahlstrøm et al., 2002; Cowton et al., 2012; Mernild and Hasholt, 2009; Rennermalm et al., 2012). Instead, these losses are inferred from satellite gravity anomalies (Chen et al., 2011; Harig and Simons, 2012; Luthcke et al., 2006; Ramillien et al., 2006; Velicogna and Wahr, 2005), remotely-sensed elevation changes at the ice sheet surface (Krabill et al., 2004; Pritchard et al., 2009) or surface mass balance models (Box et al., 2006; Van den Broeke et al., 2009a; Ettema et al., 2009; Fettweis, 2007; Hanna et al., 2008; Mernild et al., 2009, 2010b; Vernon et al., 2013). All of these methods have uncertainties when used to estimate meltwater fluxes exiting the ice sheet. For example, gravity and altimetry measurements cannot separate dynamic losses from meltwater losses without relying on surface mass balance models (Krabill et al., 2004), assumptions about geographic distribution of dominant mass loss processes (Pritchard et al., 2009), or models for glacial isostatic adjustments and volume to mass conversions (Shepherd et al., 2012). Runoff estimates inferred from surface mass balance models agree reasonably well, ranging between 232 and $333 \mathrm{~km}^{3} \mathrm{yr}^{-1}$ between 1958 and 2007 (including models with $98 \%$ of the time period: Box et al., 2006; Ettema et al., 2009; Fettweis, 2007; Hanna et al., 2008; and Mernild and Liston, 2012). However, this model agreement masks large differences in parameterization, for example, differ- ent treatment of meltwater refreezing in firn results in 13$49 \%$ retention of average meltwater production (Box et al., 2006; Ettema et al., 2009; Fettweis, 2007; Hanna et al., 2008; Janssens and Huybrechts, 2000; Mernild and Liston, 2012). Furthermore, all models ignore water storage in supraglacial lakes, which are abundant on the Greenland ice sheet (Selmes et al., 2011).

Here, ice sheet englacial meltwater retention and duration are estimated for a small watershed $\left(36-64 \mathrm{~km}^{2}\right)$ in the region near Kangerlussuaq, southwestern Greenland. To this end, modeled ice sheet surface meltwater runoff volumes are compared with proglacial river discharge measured $2 \mathrm{~km}$ downstream from the ice margin to quantify runoff deficit and surplus. Ice sheet runoff deficit and surplus are directly indicative of internal ice sheet meltwater retention and release, because (1) there are no significant proglacial or supraglacial lake storages, (2) terrestrial fluxes from groundwater and/or snowmelt are limited due to a very small proglacial area (only $6-12 \%$ of the total watershed area), and (3) modeled runoff represents the ice sheet conditions very well as it is estimated from a surface energy balance model forced by nearby automatic weather station (AWS) data (Van As et al., 2012; Van den Broeke et al., 2011b).

\section{Study region and in situ data}

The study catchment is situated along the Greenland ice sheet's southwestern margin $\sim 30 \mathrm{~km}$ northeast of Kangerlussuaq, between the Isunnguata Sermia and Russell Glacier (Fig. 1). The study watershed is small $\left(36-64 \mathrm{~km}^{2}\right)$, and mostly ice covered with a small proglacial area $\left(4 \mathrm{~km}^{2}\right)$ consisting of exposed bedrock, tundra, loess deposits, lakes, and river alluvium. The ice sheet surface elevations within this catchment range from 500 to $860 \mathrm{~m}$ a.s.l, well below the mean equilibrium line altitude, which over the period 1991-2011 averages 1553 m a.s.l. (Van de Wal et al., 2012), and has no major supraglacial lakes.

Since 2008, hydrometeorological observations have been collected at three sites along the Akuliarusiarsuup Kuua River (Rennermalm et al., 2012) including (1) river discharge, stream water level and stream temperatures (Site AK4, Fig. 1); (2) lake stage fluctuations (Site AK5, Fig. 1); and (3) near-surface air temperatures (Site AK1 and AK2, Fig. 1). Site AK4 is upstream and therefore unaffected by episodic jökulhlaups from a large proglacial lake in this region (e.g., Russell et al., 2011). Meteorological observations on the ice sheet were acquired at three AWSs labeled S5, KAN_L, and S6 in Fig. 1 at 490, 670, and $1020 \mathrm{~m}$ a.s.1., respectively (KAN_L from Van As et al., 2011, 2012; and S5 and S6 from Van den Broeke et al., 2011a), and observations on the tundra were from Kangerlussuaq airport (data access from National Climatic Data Center, 2011). These stations are situated along the K-transect, which is an array of eight surface mass balance observation points operational since 


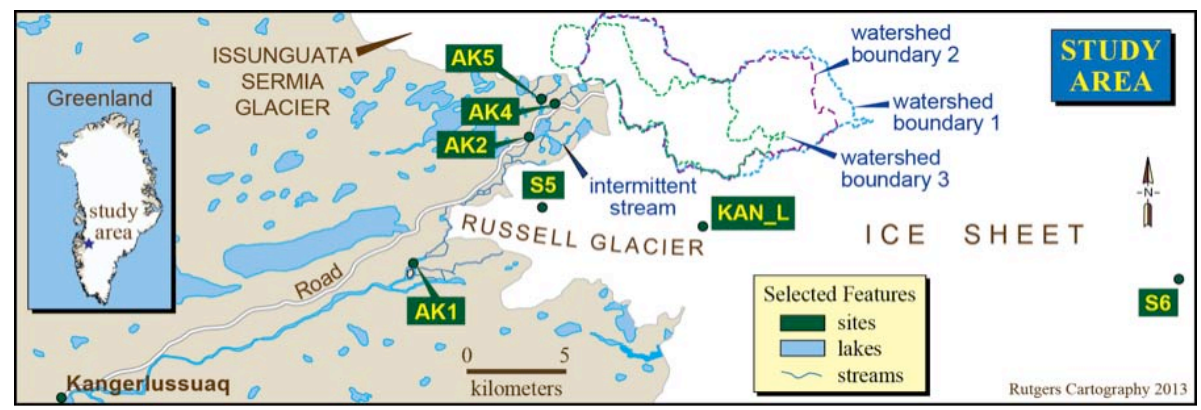

Fig. 1. (a) Map of study area showing monitoring installations for proglacial river discharge (AK4), and its estimated watershed boundaries (1, 2, and 3), nearby lake-level (AK5), and air temperature (AK1 and AK2) of Rennermalm et al. (2012). Supraglacial AWS monitoring sites S5 and S6 of van den Broeke et al. (2011a) and KAN_L of Van As and Fausto (2011), and Van As et al. (2012) are also shown. Land AWS observations are recorded at Kangerlussuaq.

1990, that extends $141 \mathrm{~km}$ into the ice sheet (Van de Wal et al., 2005).

\section{Methods}

River discharge was determined by relating 36 discharge measurements with half-hourly stream water level observations (Rennermalm et al., 2012) (rating curve $F_{1}$, Fig. 2b). Data were collected with high-precision Price Type-AA current meters, and Solinst Level- and Barologgers. River discharge uncertainty is $22 \%$ of half-hourly observations, updated from Rennermalm et al. (2012). At Site AK4, river discharge was estimated between 9 June 2008 and 20 April 2011. At Site AK5, which is downstream a neighboring watershed, water levels were measured between 2 June 2007 and 19 August 2008. To include the 2008 melt season onset at the AK4 site, its time series was retroactively estimated with a regression model using AK5 water levels and parameterized with data from an overlapping period between 9 June and 19 August 2008. This relationship was described with a linear relationship $\left(L_{\mathrm{AK} 4}=4.6 L_{\mathrm{AK} 5}-15.7\right.$ where $L_{\mathrm{AK} 4}$ is $\mathrm{AK} 4$ water level, and $L_{\mathrm{AK} 5}$ is $\mathrm{AK} 5$ water level, $R^{2}=0.64$ ).

While winter discharge uncertainty could not be quantified with conventional methods (Pelletier, 1990; WMO, 2010a, b) due to lack of wintertime sampling, development of a simple uncertainty model provides a lower boundary during freezing temperatures. This model is based on Manning's equation (e.g., Dingman, 2002) simulating a conservative scenario with an ice filled stream channel below the pressure transducer (i.e., no flow beneath the sensor) (Fig. 2a). Manning's equation is simplified similar to Rantz (1983) by assuming that Manning's roughness coefficient, $n$, and stream surface slope, $S$, are constant, and by relaxing the $2 / 3$ exponent for hydraulic radius, $R_{\mathrm{h}}$, (i.e., cross sectional area of flow divided with the wetted portion of the flow perimeter):

$Q=\mathrm{AV}=a A\left(R_{\mathrm{h}}\right)^{b}$, a)

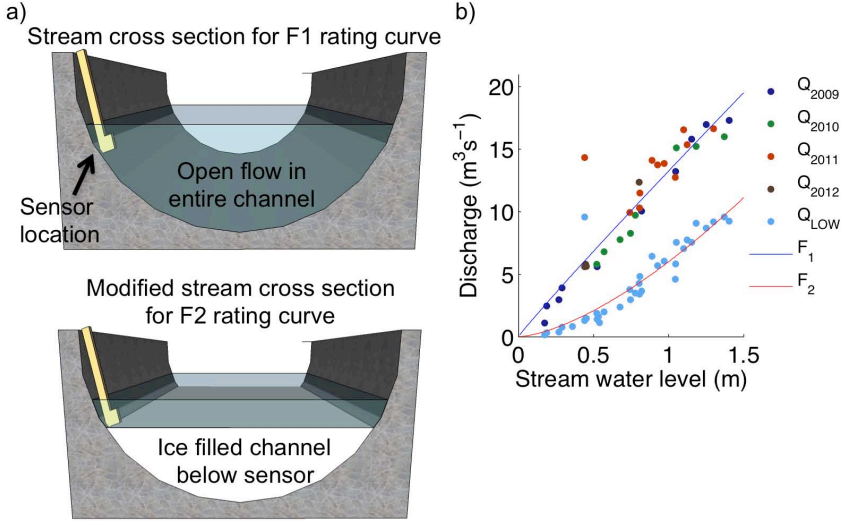

Fig. 2. (a) Schematic sketch of stream cross section in summer used to determine rating curve $F_{1}$ (top), and under the hypothetical scenario of an ice filled channel below sensor used to determine rating curve $F_{2}$ (bottom). (b) Discharge rating curves $F_{1}$ fitted to observed discharge in 2009-2012 $\left(Q_{2009}, Q_{2010}, Q_{2011}, Q_{2012}\right)$ and $F_{2}$ fitted to observations modified ( $\left.Q_{\mathrm{LOW}}\right)$ with the assumption of an ice filled channel below sensor.

where $Q$ is discharge, $a$ is a constant (equal to $S^{1 / 2} / n$ in Manning's equation), $A$ is stream cross sectional area, and $b$ is the relaxed 2/3 exponent in Manning's equation. Power law parameters $a$ and $b$ were estimated with MATLAB nonlinear least squares fitting routine using all 36 open water observations of discharge and hydraulic radius ( $F_{1}$ rating curve, $\left.R^{2}=0.95\right) . Q$ during freezing conditions was determined using Eq. (1) with $R_{\mathrm{h}}$ and $A$ modified to only include the area above the pressure transducer installation (see sketch in Fig. 2a), and multiplying with an arbitrary factor of 0.8 to account for a situation where $S$ and $n$ would reduce overall winter flow. These modified values of $Q$ were used to construct a power-law discharge rating curve ( $F_{2}$ rating curve) using MATLAB non-linear least squares fitting (Fig. 2b).

Two time series of discharge were constructed by (1) applying $F_{1}$ rating curve, hereafter $Q$; and (2) applying the $F_{1}$ except at times with subzero stream temperatures (time series 
was filtered with a 10 day moving average) when $F_{2}$ was applied, hereafter $Q_{\text {LOW. }}$.

Three possible ice sheet watershed realizations upstream of site AK4 were derived to quantify uncertainty in drainage area delineation. The first watershed was determined with methods derived from terrestrial land surface hydrology approximating hydraulic potential with elevation (e.g., Dingman, 2002) by using ice sheet surface topography to dictate boundaries and water flow directions. The second and third watershed delineations capture the influence of ice overburden pressure on the hydraulic potential by using both surface and basal topography (Cuffey and Paterson, 2010; Lewis and Smith, 2009; Shreve, 1972). Both methods are based on simplifications of ice sheet meltwater flow. The former method assumes that any en- and subglacial flow mirrors supraglacial flow patterns. The latter method is more sophisticated by assuming that water pressure equals ice overburden pressure, but effectively considers the ice sheet to be floating on a film of water (Cuffey and Paterson, 2010). In reality, hydraulic potential near the ice sheet margin is more likely to be spatially heterogeneous, where meltwater flows in a channelized system with lower water pressures (Cowton et al., 2012) as well as in preferential flow paths in pipes and fractures (Cuffey and Paterson, 2010). Thus, none of these three watershed delineations may be representative for the actual ice sheet catchment upstream of AK4, but rather provide a range where it may be found.

Watershed $1\left(\mathrm{~W} 1\right.$, ice area $60 \mathrm{~km}^{2}$ ) was delineated from surface topography alone, similar to Mernild et al. (2010a), using the ASTER GDEM2 surface elevation dataset (ASTER GDEM Validation team, 2009). ASTER GDEM2 provides high-resolution gridded elevations $(30 \mathrm{~m}$ horizontal resolution) with an average vertical precision of $17 \mathrm{~m}$ (95\% confidence interval), and agrees well with ICESat (Ice, Cloud, and land Elevation Satellite) surface elevation observations near the ice margin (Carabajal, 2011). Watersheds 2 and 3 (W2 and $\mathrm{W} 3$, ice area $31 \mathrm{~km}^{2}$ and $50 \mathrm{~km}^{2}$, respectively) were delineated based on the hydraulic potential surface calculated using ASTER GDEM2, and interpolated point basal topographic data from Multichannel Coherent Radar Depth Sounder (MCoRDS) L2 Ice Thickness (IRMCR2) data (Allen, 2010). Two delineations were made due to uncertainties in basal topography data in this study area, which are sparse, and include low quality and possibly unreliable data. Erroneous basal topography data west of $49.9^{\circ} \mathrm{W}$ were identified as points with extremely shallow ice $(<20 \mathrm{~m})$ where thicker ice is expected (judgment from field visits) and ignored in the delineation of W3. However, removal of these points resulted in patchy spatial coverage west of $49.9^{\circ} \mathrm{W}$, which may disproportionately influence any remaining, and unidentified erroneous data (Fig. 3). Thus, W2 was created only using MCoRDS data east of $49.9^{\circ} \mathrm{W}$, of which the high data density ensures better delineation quality (Fig. 3). The W3 ice sheet area is only $57 \%$ of W1 area and should be considered a lowest boundary for the true watershed area.

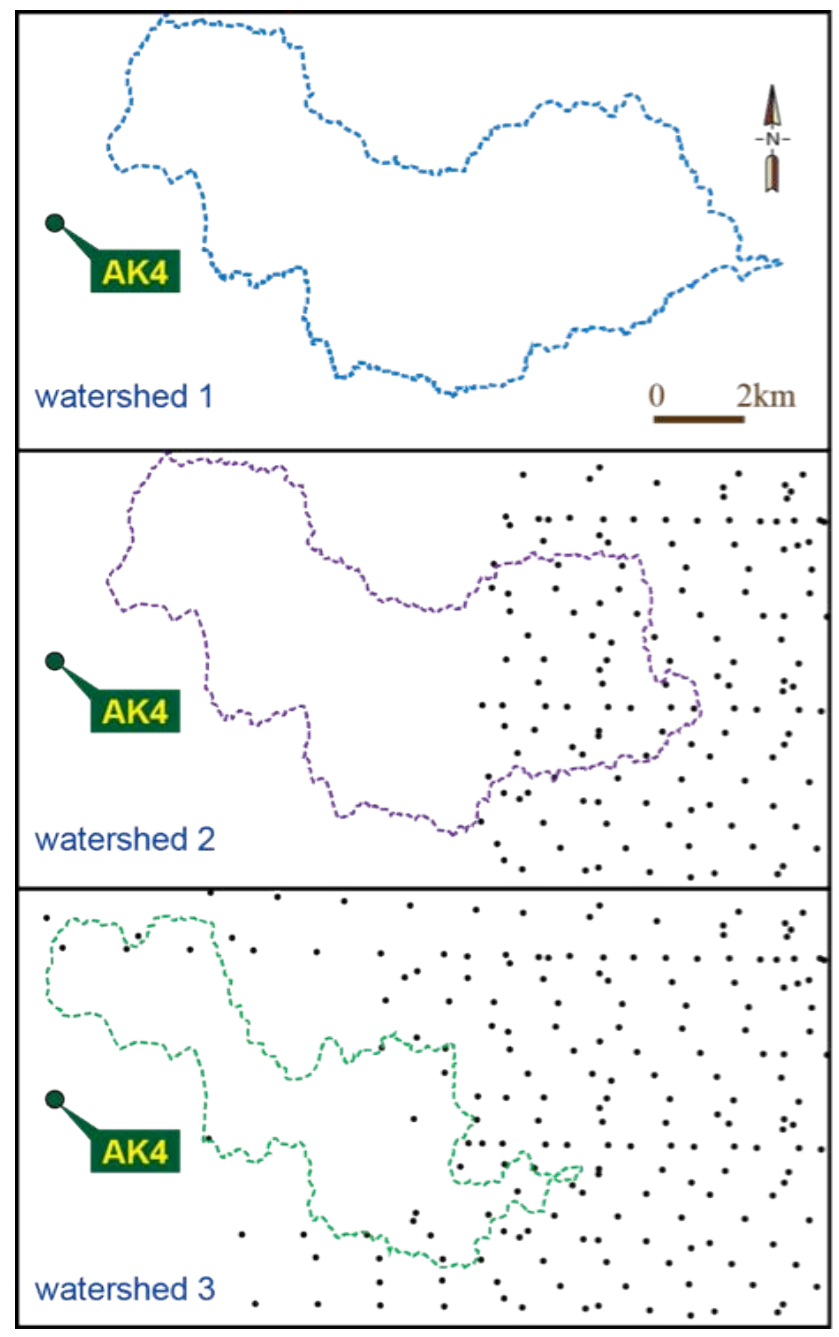

Fig. 3. Ice sheet watersheds upstream of site AK4 (excluding catchment proglacial area) and spatial distribution of MCoRDS L2 bedrock elevation data (black dots, only every 100th data point is shown) included in flow direction calculations. Watershed 1 is derived using only surface topography from ASTER GDEM2 (top panel). Watershed 2 (middle panel) and watershed 3 (bottom panel) are derived from a hydraulic potential surface determined from ASTER GDEM2 and MCoRDS L2 bedrock data. While all MCoRDS data points were used to determine watershed 3, only data points from the high data density region east of $49.9^{\circ} \mathrm{W}$ were included in watershed 2 .

Daily ice sheet runoff at AWS stations were determined with a surface mass balance model (uncertainty of runoff estimates: $15 \%$ of daily estimates) (Van As et al., 2012) using inputs of air pressure, temperature, humidity, wind speed, and downward short and longwave radiation from K-transect AWS stations (Van den Broeke et al., 2011a) and Greenland Analogue Project (GAP)/PROMICE (Van As et al., 2011, 2012) networks. In lieu of in situ precipitation measurements, liquid precipitation was estimated from longwave radiation measurements (by assuming that longwave radiation 
variability is correlated with cloudy conditions and precipitation) and validated against solid precipitation measurements (Van As, 2011; Van As et al., 2012). Any modeled energy surplus results in melt. When the surface is ice covered, or if snow pore space and temperatures in a snow layer do not facilitate refreezing, meltwater and liquid precipitation percolates to a deeper layer and may runoff once it reaches a layer with no pore space. By providing snow depth as a model input, snow refreezing capacity is realistically constrained. Superimposed ice layers (ice forming on top of snow and firn) or internal ice layer causing perched water tables, are marginal processes in this area due to shallow snow depth cover and therefore were not examined in detail.

Modeled daily runoff volumes $\left(\mathrm{m}^{3} \mathrm{~d}^{-1}\right)$ were interpolated in $50 \mathrm{~m}$ wide elevation bands, and watershed runoff $\left(R_{\mathrm{W} 1}\right.$, $R_{\mathrm{W} 2}, R_{\mathrm{W} 3}$ for $\mathrm{W} 1, \mathrm{~W} 2$, and $\mathrm{W} 3$, respectively) was calculated as a function of elevation band runoff and its respective area fraction. The 2008 melting season onset predates the Van As et al. (2012) dataset, and was estimated with a linear regression model based on a similar surface energy balance model applied only at K-transect AWS S5 and S6 (Van den Broeke et al., 2008, 2009b, 2011a). While AWS S5 is on the Russell glacier tongue and known to be influenced by air heated over the surrounding tundra (Van den Broeke et al., 2011a), inclusion of GAP/PROMICE KAN_L and AWS S6 ensures that the watershed energy balance is representative of colder conditions further inland. Given that S5, KAN_L, and S6 are located just outside of W1, W2, and W3, we implicitly assume that elevation is a dominant control on ice sheet runoff.

Characterizations of meteorological conditions on the ice sheet and in the proglacial tundra environment were examined with near-surface air temperatures obtained from the Kangerlussuaq AWS 042310 (data accessed from National Climatic Data Center, 2011), AWS S5 (due to its full time series during the study period), and AK1 and AK2 Barologgers (unshielded and only providing reliable temperature data for winter and early spring). Snow depth was retrieved from AWS S5 and AWS S6.

\section{Results}

The lower bounds for winter discharge ( $\left.Q_{\mathrm{LOW}}\right)$ and runoff from the smallest watershed realization (W3) can produce a match between cumulative ice sheet runoff and river discharge over the three-year period (Fig. 4). However, $Q_{\text {LOW }}$ and $R_{\mathrm{W} 3}$ are conservative estimates and should be considered absolute lowest boundaries, thus water budget closure is unlikely. The other, perhaps more realistic catchments (W1 and W2) produce a surplus of ice sheet runoff relative to river discharge at the end of the three-year period (Fig. 4). Uncertainties of winter discharge measurements exacerbate deficit in river discharge relative to $R_{\mathrm{W} 1}$ and $R_{\mathrm{W} 2}$. Thus, two scenarios are plausible: (1) runoff exceeds river discharge over a three-year period suggesting ice sheet meltwater retention

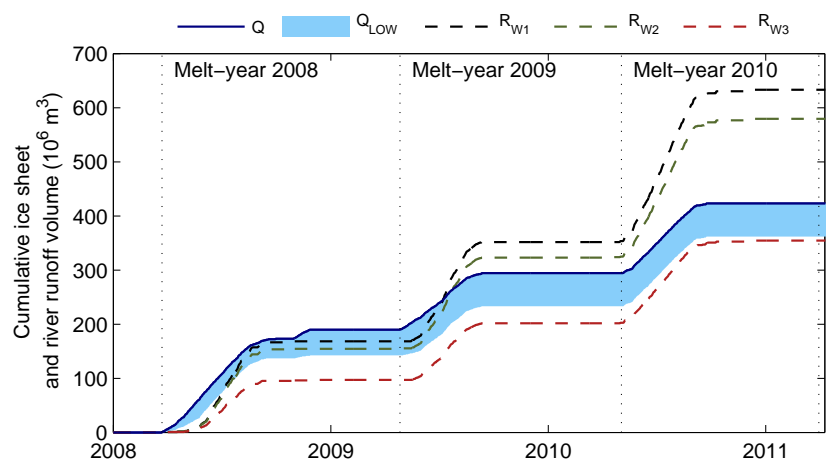

Fig. 4. Cumulative river discharge $Q$, uncertainty range from winter discharge $Q_{\mathrm{LOW}}$, and ice sheet watershed runoff from W1, W2, and W3 $\left(R_{\mathrm{W} 1}, R_{\mathrm{W} 2}, R_{\mathrm{W} 3}\right)$ for the melt-years 2008,2009 and 2010. While watersheds 1 and 2 have ice sheet runoff surpluses relative to river discharge at the end of 2010, watershed 3 has a deficit. A meltyear is defined as the time period between river discharge onset in two consecutive years and is designated after the year that it begins.

(W1 and W2); (2) ice sheet runoff is less than river discharge at the end of the three-year period suggesting an englacial water source. In subsequent paragraphs, analysis of W1 and $\mathrm{W} 3$ will be presented because results for $\mathrm{W} 2$ and $\mathrm{W} 1$ are similar.

For each melt-year within the three-year period, watersheds switch from net release of ice sheet meltwater at the end of melt-year 2008 to net retention at the end of meltyears 2009 and 2010 (Fig. 5). An exception to this occurs in W1 during 2008 when winter discharge uncertainties $\left(Q_{\text {LOW }}\right)$ are considered. Winter discharge uncertainty reduces meltwater release, but only in W1, in melt-year 2008, does $Q_{\text {LOW }}$ reverse balance between ice sheet meltwater retention (i.e., ice sheet runoff surplus relative to river discharge) and release (i.e., ice sheet runoff deficit). Meltwater retention in $\mathrm{W} 3$ is less than in $\mathrm{W} 1$, and the $\mathrm{W} 3$ water budget is almost in balance in 2009 and 2010 with ice sheet runoff exceeding river discharge resulting in retention of $1-14 \%$ and $15 \%$ of melt-year ice sheet runoff volume, respectively. Given that actual ice sheet runoff probably exceeds $R_{\mathrm{W} 3}$, relatively large net ice sheet meltwater retention in 2009 and 2010 is more likely. In contrast to W3, W1 ice sheet runoff exceeds river discharge resulting in retention of $44-51 \%$ of melt-year ice sheet runoff volume in 2009 and $54 \%$ in 2010. This meltwater generated on the ice sheet surface and not escaping to the river is presumably retained in en- or subglacial storages, given lack of supra- and proglacial lake storage.

Daily summer river discharge and ice sheet runoff during periods with surface melting co-vary strongly with a linear relationship in all years (the correlation coefficient is 0.46, 0.85, 0.85 in 2008, 2009, and 2010 for $Q$ and $R_{\mathrm{W} 1}$ ). Strongest covariability between daily river discharge and ice sheet runoff is found during the warm season (Figs. 6, 7). During this time, runoff magnitude and variability are 


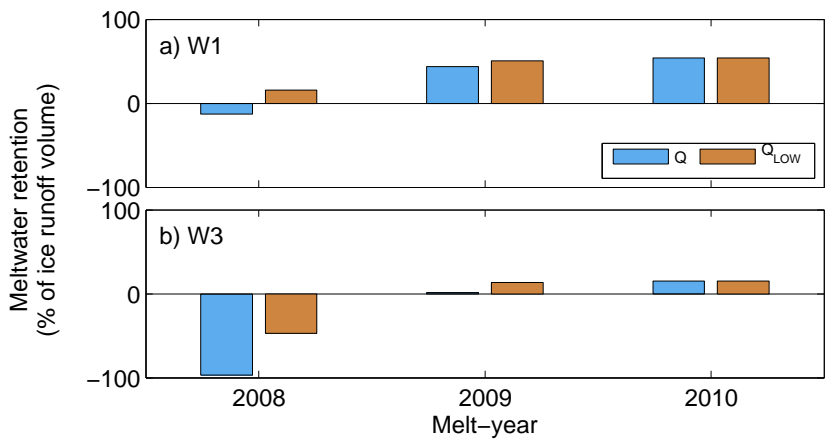

Fig. 5. Ice sheet meltwater retention for each melt-year from 2008 to 2010 as a percentage of ice sheet runoff volume for (a) W1 and (b) W3 determined with AK4 discharge $(Q)$ and discharge adjusted for winter uncertainty ( $Q_{\mathrm{LOW}}$ ) (negative values represent meltwater release). W1 and W3 represent two diametrically opposed scenarios where $\mathrm{W} 1$, the largest watershed estimate, is dominated by meltwater retention, while $\mathrm{W} 3$, the smallest watershed estimate, is dominated by release.

proportional to watershed size. $R_{\mathrm{W} 1}$ tends to be larger and more variable, while $R_{\mathrm{W} 3}$ is almost equal to $Q$ for most of the melting season. Watershed runoff and river discharge agreement improve with consideration of winter discharge errors in the early melting seasons of 2008 and 2009. However, considerable discrepancies between river discharge and ice sheet runoff are noted: spring 2008; fall 2008; and spring 2009. Regardless of how watershed runoff is determined, river discharge onset generally precedes ice sheet runoff. In 2008 and 2009 , river flow commences within 0-2 days of isolated ice sheet runoff pulses, but is followed by 18-23 days without significant runoff (Table 1). In 2010, river discharge lags ice sheet runoff onset by 4 days. In 2008, river discharge onset is 31 days earlier than ice sheet thaw onset at S5, but occurs within 3 days of proglacial thaw at Kangerlussuaq (Table 1). In 2009 and 2010, opposite patterns are detected when river discharge onset coincides with thaw at S5 (within 1-3 days), but is considerably delayed compared to thaw at Kangerlussuaq (32-35 days).

Three prolonged periods of river flow occur at times with no significant ice sheet surface meltwater production, suggesting a cold-season release of englacial meltwater or proglacial snowmelt (river surplus is shown as negative values in Figs. 6b, c and 7b, c). One period occurs in winter of 2008 between 31 October and 28 November. The two others occur in pre-melting season months (March and April) between 23 March and 16 April 2008 and between 27 April and 15 May 2009. While cold-season river flow event magnitudes are reduced by factoring in wintertime discharge estimation errors, they are still present (Figs. 6c, 7c).

The 2008 winter runoff event is identified as a water pressure anomaly between 30 October and 28 November (Fig. 8). It is accompanied by a rapid temperature increase in the stream channel from -5.5 to $-0.5^{\circ} \mathrm{C}$ between 26 and 28 a)
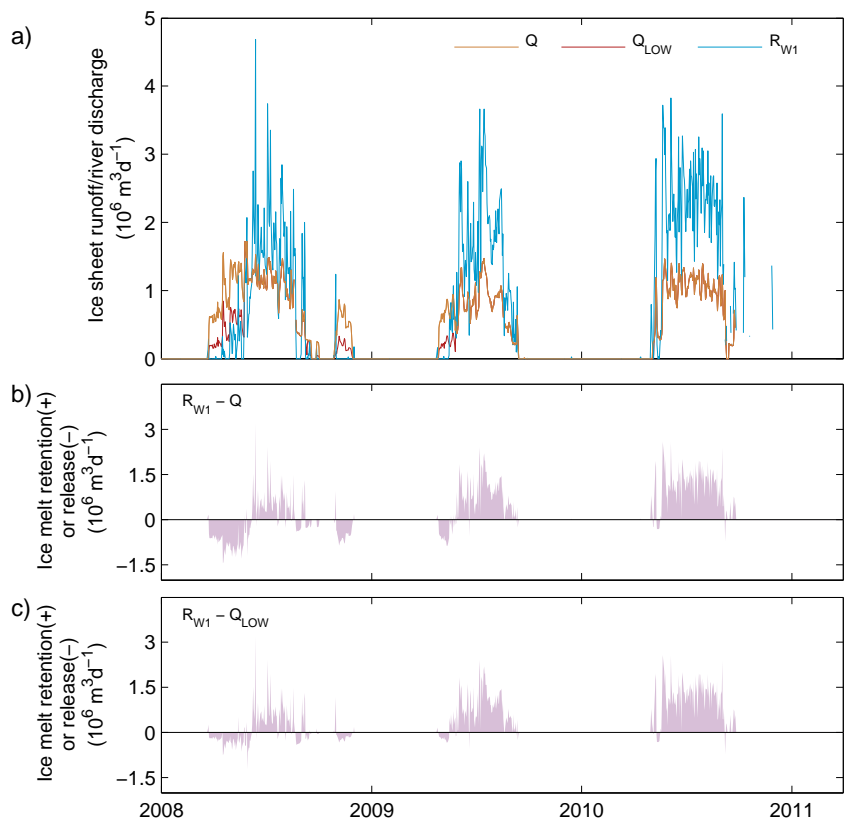

Fig. 6. (a) Daily ice sheet runoff volume from $\mathrm{W} 1\left(R_{\mathrm{W} 1}\right)$, river discharge $(Q)$, and river discharge adjusted for winter uncertainty ( $Q_{\text {LOW }}$ ) for melt-years 2008-2010, (b) ice sheet meltwater retention/release relative to river discharge, and (c) relative to river discharge adjusted for winter uncertainty.

a)
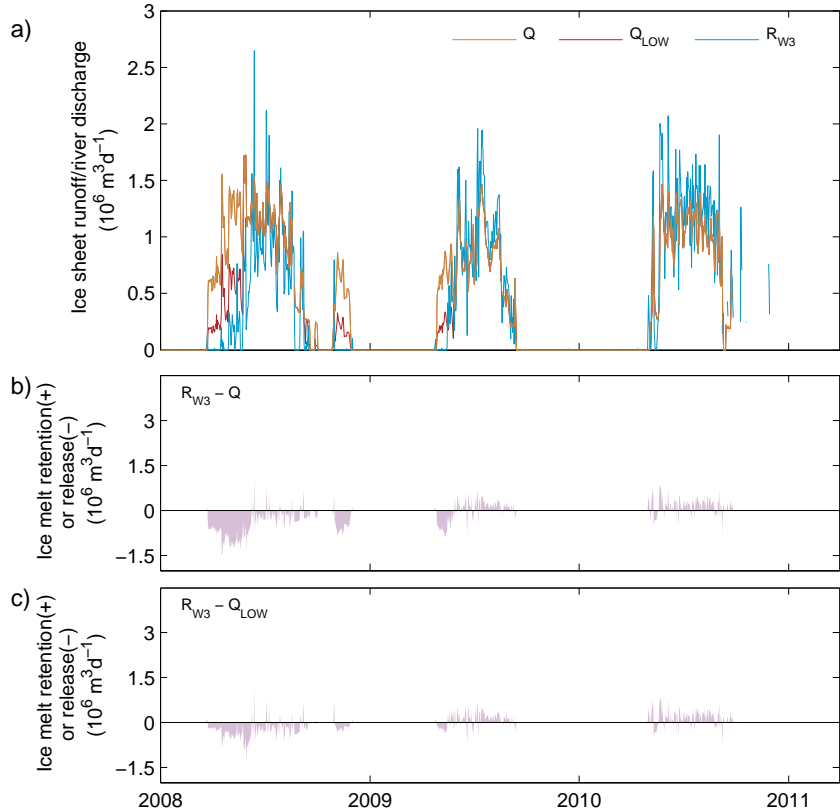

Fig. 7. Same as Fig. 6 but for W3 ( $\left.R_{\mathrm{W} 3}\right)$.

October, followed by a period of constant near-zero (average is $-0.5^{\circ} \mathrm{C}$ ) stream channel temperature until 28 November (Fig. 8) indicative of a water phase change from frozen to liquid. This river discharge anomaly is preceded by a small ice sheet runoff pulse between 27 and 30 October 2008, 
Table 1. Onset of river discharge, ice sheet surface runoff, and thaw proxy (dates when cumulative near-surface air temperature exceed $0{ }^{\circ} \mathrm{C}$ at S5 and Kangerlussuaq AWS). Dates within parentheses shows isolated melting events before onset of continuous melting.

\begin{tabular}{llll}
\hline Site & 2008 & 2009 & 2010 \\
\hline Flow onset & & & \\
\hline River discharge (Site AK4) & $23 \mathrm{Mar}$ & $27 \mathrm{Apr}$ & 4 May \\
Ice sheet watershed runoff & $16 \mathrm{Apr}$ (22-23 Mar) & $15 \mathrm{May}$ (25 Apr) & 30 Apr (13 Apr) \\
\hline Thaw onset & & & \\
\hline S5 (ice sheet) & $23 \mathrm{Apr}$ & $26 \mathrm{Apr}$ & $1 \mathrm{May}$ \\
Kangerlussuaq (proglacial) & $26 \mathrm{Mar}$ & $5 \mathrm{Mar}$ & $26 \mathrm{Mar}$ \\
\hline
\end{tabular}

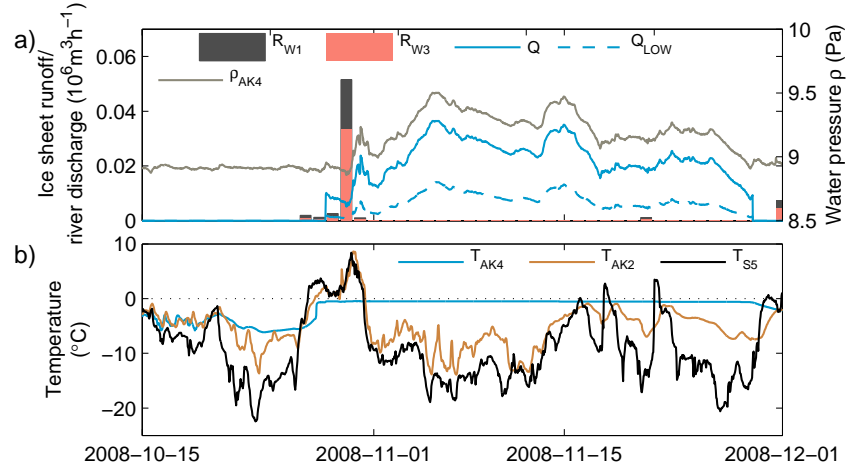

Fig. 8. Ice sheet, river, and proglacial conditions during the October-November 2008 runoff event, including discharge with ( $Q_{\text {LOW }}$ ) and without winter error compensation $(Q)$, average hourly ice runoff from $\mathrm{W} 1\left(R_{\mathrm{W} 1}\right)$ and $\mathrm{W} 3\left(R_{\mathrm{W} 3}\right)$ and sensor water pressure $\left(\rho_{\mathrm{AK} 4}\right) \mathbf{( a )}$; and temperatures measured in the stream channel $\left(T_{\mathrm{AK} 4}\right)$, in the proglacial area by site $\mathrm{AK} 2\left(T_{\mathrm{AK} 2}\right)$, and on the S5 ice sheet AWS site $\left(T_{\mathrm{S} 5}\right)(\mathbf{b})$. A short ice sheet runoff pulse ( $R_{\mathrm{W} 1}$ and $\left.R_{\mathrm{W} 3}\right)$ that accompanied above $0{ }^{\circ} \mathrm{C}$ ice sheet $\left(T_{\mathrm{S} 5}\right)$ and proglacial $\left(T_{\mathrm{AK} 2}\right)$ surface air temperatures precedes a longer river discharge event ( $Q$ and $Q_{\mathrm{LOW}}$ ). Comparison of surface air and stream channel temperatures reveals when the stream channel pressure transducer sensor is exposed to air (15-28 October), and when it is not (28 October-1 December). On 1 November, stream channel pressure increases above background noise and stream channel temperatures rise rapidly to near-zero suggesting that the AK4 stream channel sensor is submerged by liquid water after this date.

coinciding with above-freezing near-surface air temperatures at both AK2 and S5. River discharge peaks on 5 November, seven days after runoff peaks on the ice sheet.

Two river discharge events observed in March/April 2008 and April/May in 2009 are also registered as pressure anomalies (Figs. 9, 10). In March/April 2008, discharge is inferred from a sensor at AK5 installed at a lake bottom and cannot be used to determine stream temperatures at AK4 during this anomaly. In contrast, April/May 2009 discharge is determined from a sensor at AK4. In 2009, stream temperature increases by $5^{\circ} \mathrm{C}$ on $27 \mathrm{April}$, in concert with rising water pressure. Although AK4 stream temperatures remain

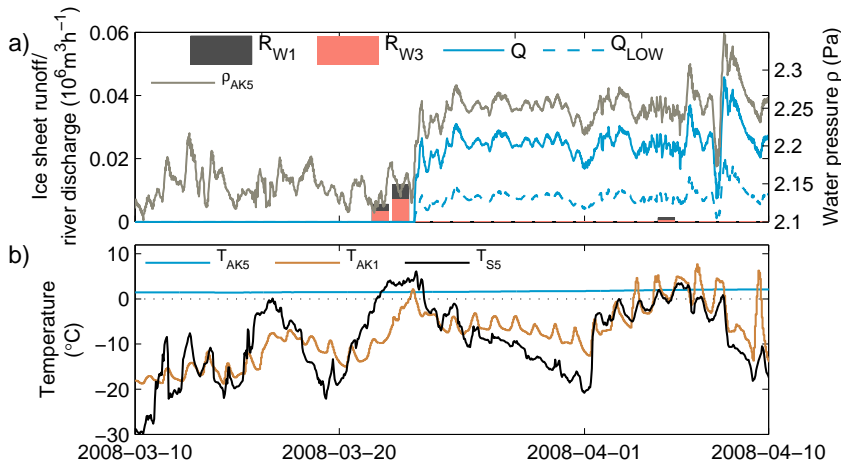

Fig. 9. Same as Fig. 8, but for the 2008 pre-melting season runoff event (due to lack of data $T_{\mathrm{AK} 5}$ are shown instead of $\left.T_{\mathrm{AK} 4}\right)$. A short ice sheet runoff pulse between 22 and 23 March $\left(R_{\mathrm{W} 1}\right.$ and $\left.R_{\mathrm{W} 3}\right)$ precedes a marked increase in water pressure at AK5 $\left(\rho_{\mathrm{AK} 5}\right.$; AK4 site was not operational at this time and $Q$ is extrapolated from site AK5). The ice sheet runoff between 22 and 23 March coincide with a short period with above $0{ }^{\circ} \mathrm{C}$ ice sheet $\left(T_{\mathrm{S} 5}\right)$ and proglacial temperatures $\left(T_{\mathrm{AK} 1}\right)$ at Sites $\mathrm{S} 5$ and $\mathrm{AK} 1$, respectively. Constant lake temperatures $\left(T_{\mathrm{AK} 5}\right)$ during this period indicate unfrozen conditions at the AK5 lake bottom.

below freezing, this may be indicative of a shallow layer of thawing ice by the pressure transducer. Similar to the 2008 October/November discharge event, these two pre-melting season events are preceded by small runoff pulses (22-23 March 2008 and 25 April 2009), and short periods (hours) of above $0^{\circ} \mathrm{C}$ air temperatures on the ice sheet and in the proglacial environment.

Ice sheet melting preceding and during these three coldseason events are considerably smaller than river discharge regardless of watershed delineation, discharge calculation method and uncertainty bounds (Table 2). Even considering the most conservative scenario, using proglacial river discharge with winter discharge errors $\left(Q_{\mathrm{LOW}}\right)$ and ice sheet runoff from W1, cold-season events are 297, 7, and $300 \%$ larger than runoff in winter 2008, fall 2008, and winter 2009, respectively. While watershed configuration has little impact on total meltwater losses during these events (runoff from W1 was only 6-13\% larger than W3 during these events), 
Table 2. River discharge and ice sheet runoff during cold-season events.

\begin{tabular}{llll}
\hline Site & 2008 winter & 2008 fall & 2009 winter \\
\hline Time period & 23 Mar-16 Apr & 29 Oct-31 Nov & 27 Apr-15 May \\
\hline River discharge $Q\left(10^{6} \mathrm{~m}^{3}\right)$ & $29 \pm 0.2$ & $34 \pm 0.2$ & $23 \pm 0.2$ \\
River discharge $Q_{\text {LOW }}\left(10^{6} \mathrm{~m}^{3}\right)$ & $9.1 \pm 0.6$ & $10 \pm 0.6$ & $10 \pm 0.6$ \\
Ice sheet runoff $R_{1}\left(10^{6} \mathrm{~m}^{3}\right)$ & $0.03 \pm 0.005$ & $1.4 \pm 0.2$ & $0.03 \pm 0.005$ \\
Ice sheet runoff $R_{3}\left(10^{6} \mathrm{~m}^{3}\right)$ & $0.03 \pm 0.004$ & $1.3 \pm 0.2$ & $0.03 \pm 0.005$ \\
$\begin{array}{l}\text { Maximum water level }(\mathrm{m}) \\
\text { Hypothetical snow depth }(\mathrm{m})\end{array}$ & 0.96 & 0.76 & 0.76 \\
$\begin{array}{l}\text { (10\% of water density) } \\
\text { Hypothetical snow depth }(\mathrm{m})\end{array}$ & 1.9 & 7.6 & 7.6 \\
$(50 \%$ of water density) & & 1.5 & 1.5 \\
\hline
\end{tabular}

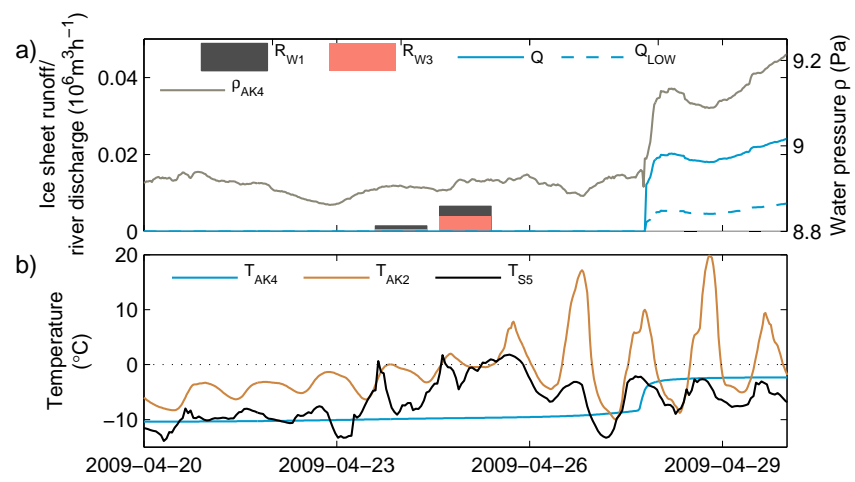

Fig. 10. Same as Fig. 8, but for the 2009 pre-melting season runoff event. A short ice sheet runoff pulse $\left(R_{\mathrm{W} 1}\right.$ and $\left.R_{\mathrm{W} 3}\right)$ on 25 April that accompanied above $0{ }^{\circ} \mathrm{C}$ ice sheet $\left(T_{\mathrm{S} 5}\right)$ and proglacial $\left(T_{\mathrm{AK} 2}\right)$ surface air temperatures precedes river runoff onset by 2 days $(Q$ and $Q_{\text {LOW }}$ ). Stream channel pressure on 27 April increases simultaneous with a $5{ }^{\circ} \mathrm{C}$ rise of stream channel temperatures, which are suggestive of phase change and liquid water flow after this date.

the choice of discharge calculation method has a large impact (discharge without corrections were 123-229\% larger than with corrections).

Although precipitation, snowmelt, and/or measurement uncertainties and errors cannot be ruled out entirely, coldseason release of englacially stored meltwater is a likely explanation for stream channel pressure increases recorded during cold-season events. Recorded pressure anomalies correspond to maximum water depths of $0.96,0.76$, and $0.76 \mathrm{~m}$ respectively (Table 2), which is well within site AK3's typical flow depths $(0-1.4 \mathrm{~m})$. Snow accumulation is a less likely explanation, requiring depths of 7.6-9.6 $\mathrm{m}$ and $1.5-1.9 \mathrm{~m}$, using respectively 10 and $50 \%$ of water density (Table 2). Such depths are markedly greater than typical winter snow accumulation at the S5 and S6 AWS sites of 0.16 and $0.33 \mathrm{~m}$, respectively.

\section{Discussion}

This study finds that a large fraction of ice sheet surface runoff produced each melt-year may be retained somewhere within the watershed; $52 \pm 1.6 \%$ in 2009 and $54 \pm 1.4 \%$ in 2010 (Fig. 5a). In 2008 and 2009, 4-27\% (12-37\% with $Q, 10-20 \%$ with $\left.Q_{\mathrm{LOw}}\right)$ of ice sheet meltwater is released with a 1-6 month delay in the cold season, but cannot close meltwater input and output gaps, except if the ice sheet catchment areas were very small (W3). Uncertainties associated with runoff and discharge estimation prohibit discerning whether net meltwater retention or release took place in 2008 (Fig. 5a). Large net annual meltwater release in 2008 is only possible from an upstream ice sheet watershed that is very small (i.e. W3, Fig. 5b). Few basal topographic data and low quality data near the ice margin suggest that the true watershed is larger than W3. Even with availability of high quality basal topography data, calculations of hydraulic potential ignore preferential flow paths in en- and subglacial conduits thereby only providing an approximation of the true watershed. Assuming that the true catchment is larger than W3 and smaller than $\mathrm{W} 1$, and that effective ice sheet watershed area remains the same from one year to another, meltwater is likely to be retained in the ice sheet during the three-year study period.

Lack of substantial surface meltwater lakes on the ice sheet and in the proglacial study area indicate that surface meltwater not exiting in the AK River must have been stored in subglacial till or ice sheet macropores (Fountain and Walder, 1998). Glacier macropores, i.e., the volume fraction of crevasses and fractures, is a potential storage mechanism for some retained meltwater. Typical macroporosity values in glaciers are $\sim 1 \%$ (Anderson, 2004; Fountain and Walder, 1998; Harper and Humphrey, 1995), and must be augmented by storage in subglacial cavities and till, since the volume fraction of ice sheet runoff surplus in $2009(0.3 \%)$ and $2010(0.5 \%)$ would saturate macropores in $2-3 \mathrm{yr}$. Some retained meltwater probably refreezes during winter, but cold-season discharge events show a substantial amount of 
unfrozen water throughout winter. Some ice sheet meltwater may surpass the river channel altogether and be transported as groundwater flow and in the river hyporheic zone, but the presence of permafrost probably limits the magnitude of this loss.

Evidence for delayed ice sheet surface meltwater release is found on daily, seasonal and multiyear timescales. First, ice sheet surface runoff and downstream river discharge have high co-variability in summer months. Amplitude of river discharge is dampened relative to ice sheet runoff, which is typical of meltwater transformation in supra-, en-, and subglacial environments during its passage to rivers at the ice terminus (Fountain and Walder, 1998). Second, three coldseason meltwater releases during times with insignificant ice sheet surface melting suggest that the CHS system can retain meltwater for months after the end of the melting season in September. Finally, ice sheet surface runoff and river discharge are not in balance, resulting in net meltwater storage two years in a row, suggesting meltwater retention on timescales beyond one year. This is verified by modeling of ice sheet hydrology in a western Greenland watershed, where unfrozen ice sheet meltwater was retained internally over multiple years (Colgan et al., 2011). Delays between ice sheet runoff and downstream river discharge on monthly and multiyear timescales are not unique to the Greenland ice sheet, and have been identified for other Arctic glaciers (Hagen et al., 2003; Hodson, 2005; Jansson et al., 2003; Stenborg, 1965; Wadham, 2000).

Three cold-season meltwater releases were only accompanied by modest ice sheet surface runoff, but two pieces of evidence show that river channel flow indeed did occur between 31 October and 28 November 2008, 23 March and 16 April, and 27 April and 15 May. First, stream channel pressure anomalies during cold-season events cannot be explained by the weight of dense snowpacks; instead, derived water levels and runoff are well within AK4's natural range. While a very conservative method to adjust winter discharge errors reduce cold-season river discharge, it does not eliminate flow at this time of year. Second, stream channel temperatures suggest liquid water, and/or phase change. During October 2008, stream channel temperatures co-vary with nearsurface air temperatures until 31 October because there is no water evident at AK4 (Fig. 8). However, after 1 November, stream channel temperatures rise and air temperatures remain below freezing, coinciding with stream channel pressure increase indicating flowing unfrozen water. During the 2009 pre-melt season, a sudden $5{ }^{\circ} \mathrm{C}$ stream channel temperature increase coincided with raised stream channel pressure to indicate melting and flowing water (Fig. 10). In the premelting season of 2008, meltwater release precedes ice sheet surface melting and above-freezing near-surface air temperatures (Fig. 9). Thus, despite inherent uncertainties of wintertime river low-flow observations (Pelletier, 1990) and assuming extremely reduced flow, existence of cold-season meltwater discharge is evident. Measurement uncertainties and errors are unlikely to completely account for this given that the sensor operated as expected before and after the three cold-season discharge episodes, and coherence with brief preceding ice sheet runoff events providing a potential triggering mechanism. Presence and release of unfrozen meltwater in the Greenland ice sheet at subfreezing temperatures suggests that parts of the CHS are intact in the cold season. Indeed, this possibility is confirmed by modeling studies (Colgan et al., 2011; Phillips et al., 2010, 2013), and observations with ground penetrating radar (Catania and Neumann, 2010).

Above-freezing air temperatures may provide a triggering mechanism for release of stored meltwater. During these times, a short thaw period (1-4 days) started at the S5 AWS site $30-75 \mathrm{~h}$ before they were detected in the stream. Although bursts of ice sheet runoff accompany all events, their durations are too short (1-3 days versus 18-30 days) and volumes are too small (never exceeding $14 \%$ of river discharge volume even when the most conservative estimation techniques were used) to explain all river runoff observed during these periods. A lack of significant ice sheet runoff during these months indicates that cold-season river discharge was produced during warm summer months. Additional drivers for winter release may stem from buildup of subglacial pressure as englacial meltwater drains to subglacial cavities and drainage exits close (Irvine-Fynn et al., 2011).

It is known that meltwater may be retained on the ice sheet surface in lakes (Selmes et al., 2011; Sundal et al., 2009) and percolate into firn layers (Harper et al., 2012; Humphrey et al., 2012). However, evidence presented in this study suggests that meltwater transported through englacial conduits (Catania and Neumann, 2010; Catania et al., 2008) to storage cavities in englacial and subglacial environments may remain there until short thaw events presumably trigger its release. Such subglacial storages, and delayed release, have been observed for high Arctic glaciers in Svalbard (Hodson, 2005; Wadham et al., 2001), but not previously identified for the Greenland ice sheet. In contrast, good agreement between ice sheet runoff and river discharge was found for the large Watson River watershed $\left(\sim 12500 \mathrm{~km}^{2}\right)$ in southwestern Greenland in 2009 and 2010 (Van As et al., 2012). While ice sheet runoff in the Watson River watershed was larger than observed discharge (8\% in 2009, and $19 \%$ in 2010), the AK4 study site examined here exhibited much larger ice sheet runoff (up to $118 \%$ more than river discharge in 20092010). Because the AK4 site is a subwatershed within the Watson River, this discrepancy could suggest that the AK4 site retention cannot be upscaled to the entire Watson River watershed. However, this cannot be established without Watson River winter discharge observations, which are currently unavailable. Regardless, an increase in ice sheet runoff surplus relative to river discharge from 2009 to 2010 in the Watson River indicate a non-systematic underlying driver, for example, en- and subglacial meltwater storage. 
Cold-season release may in fact be a consequence of meltwater storage within the Greenland ice sheet according to the following hypothesis: meltwater retention builds up subglacial pressures such that CHS, in the cold-season near the ice margin, remains largely intact and can rapidly reactivate in response to short-lived melt events. This hypothesis is not unique to this study. Six years of energy and mass balance studies from a Svalbard glacier reveal that years with lower than expected ice sheet meltwater export (due to internal storage) preceded years when less than usual energy was required for activating the subglacial system, perhaps due to increased subglacial pressure from larger than usual internal storage (Hodson, 2005). It is unclear how meltwater retention influences CHS evolution. Modeling and observational studies suggest that CHS seasonally evolves from an un-channelized state dominated by distributed cavities to an efficient channelized system with large conduits controlled by meltwater fluxes to the subglacial hydrologic drainage system (Schoof, 2010; Sundal et al., 2011). This influences ice sheet velocities, so that in years with strong surface melting, and thus more efficient subglacial drainage, ice sheet velocities decelerate early in the melt season (Sundal et al., 2011). To understand the importance of Greenland ice sheet meltwater retention on these processes, more observational and modeling studies must establish how common this is in other parts of Greenland, and how it is related to subglacial pressure, cold-season releases, and CHS development.

\section{Conclusions}

Greater cumulative ice sheet surface runoff relative to downstream river discharge suggests meltwater retention in enand subglacial storages up to as much as $54 \%$ of annual ice sheet runoff. However, estimation errors, particularly associated with watershed delineations, may reduce this amount and explain discrepancies between runoff and downstream river discharge resulting in very small retention. While the upper estimate of meltwater retention is a large fraction of annual ice sheet runoff (e.g., $54 \%$ ), it is less than $1 \%$ of total watershed ice volume. This is similar to observed values of glacier macroporosity, thus macropores, and sub- and englacial storage provide reasonable storage mechanisms for excess ice sheet runoff. Furthermore, alternative storages are unlikely due to lack of ice sheet firn, surface lakes, and limited proglacial area.

Three observed river runoff events outside of the regular summer melting period, and preceded by very small ice sheet runoff fluxes, are examples of 1-6 month delayed release of en- and subglacially stored water. These cold-season events cannot be explained by proglacial lake drainage (there are no significant proglacial lakes) or snow melt. Instead, stream channel temperature recordings provide strong evidence for water flow during these events. Regardless, these delayed meltwater releases do not close the watershed water budget, indicating multiyear retention of ice sheet meltwater, and evidence that parts of the Greenland ice sheet CHS may remain active year round.

Acknowledgements. This research was funded by the NASA Cryosphere Program grants NNG05GN89G and NNX11AQ38G. The authors thank S. Marshall, M. Pelto, W. T. Pfeffer, and one anonymous reviewer for constructive suggestions.

Edited by: S. Marshall

\section{References}

Ahlstrøm, A. P., Boggild, C. E., Mohr, J., Reeh, N., Christensen, E., Olesen, O., and Keller, K.: Mapping of a hydrological icesheet drainage basin on the West Greenland ice-sheet margin from ERS-1/-2 SAR interferometry, ice-radar measurement and modelling, Ann. Glaciol., 34, 309-314, 2002.

Allen, C.: IceBridge MCoRDS L2 Ice Thickness, Version 1.2. [2009-2011], , 2010.

Anderson, R. S.: Strong feedbacks between hydrology and sliding of a small alpine glacier, J. Geophys. Res.-Earth, 109, F03005, doi:10.1029/2004JF000120, 2004.

ASTER GDEM Validation team: ASTER GDEM Validation Summary Report, The Ministry of Economy, Trade, and Industry (METI) of Japan and the United States National Aeronautics and Space Administration (NASA), 2009.

Bartholomew, I. D., Nienow, P. W., Sole, A., Mair, D., Cowton, T., Palmer, S., and Wadham, J.: Supraglacial forcing of subglacial drainage in the ablation zone of the Greenland ice sheet, Geophys. Res. Lett., 38, L08502, doi:10.1029/2011GL047063, 2011.

Bindschadler, R. A., Nowicki, S., Abe-OUCHI, A., Aschwanden, A., Choi, H., Fastook, J., Granzow, G., Greve, R., Gutowski, G., Herzfeld, U., Jackson, C., Johnson, J., Khroulev, C., Levermann, A., Lipscomb, W. H., Martin, M. A., Morlighem, M., Parizek, B. R., Pollard, D., Price, S. F., Ren, D., Saito, F., Sato, T., Seddik, H., Seroussi, H., Takahashi, K., Walker, R., and Wang, W. L.: Icesheet model sensitivities to environmental forcing and their use in projecting future sea level (the SeaRISE project), J. Glaciol., 59, 195-224, doi:10.3189/2013JoG12J125, 2013.

Boggild, C. E.: Simulation and parameterization of superimposed ice formation, Hydrol. Process., 1566, 1561-1566, doi:10.1002/hyp.6718, 2007.

Boggild, C. E., Forster, R. R., and Reeh, N.: Meltwater retention in a transect across the Greenland ice sheet, Ann. Glaciol., 40, 169-173, 2005.

Box, J. E., Bromwich, D. H., Veenhuis, B., Bai, L., Stroeve, J. C., Rogers, J., Steffen, K., Haran, T., and Wang, S.: Greenland ice sheet surface mass balance variability (1988-2004) from calibrated polar MM5 output, J. Climate, 19, 2783-2800, 2006.

Box, J. E., Yang, L., Bromwich, D. H., and Bai, L. L.-S.: Greenland Ice Sheet Surface Air Temperature Variability: 1840-2007*, J. Climate, 22, 4029-4049, doi:10.1175/2009JCLI2816.1, 2009.

Box, J. E., Fettweis, X., Stroeve, J. C., Tedesco, M., Hall, D. K., and Steffen, K.: Greenland ice sheet albedo feedback: thermodynamics and atmospheric drivers, The Cryosphere, 6, 821-839, doi:10.5194/tc-6-821-2012, 2012. 
Brown, J., Harper, J. T., Pfeffer, W. T., Humphrey, N. F., and Bradford, J.: High-resolution study of layering within the percolation and soaked facies of the Greenland ice sheet, Ann. Glaciol., 52, 35-42, 2011.

Carabajal, C. C.: ASTER Global DEM Version 2.0 Evaluation Using ICESat Geodetic Ground Control, Sigma Space Corporation at NASA Goddard Space Flight Center, 2011.

Catania, G. A. and Neumann, T. A.: Persistent englacial drainage features in the Greenland Ice Sheet, Geophys. Res. Lett., 37, L02501, doi:10.1029/2009GL041108, 2010.

Catania, G. A., Neumann, T. A., and Price, S. F.: Characterizing englacial drainage in the ablation zone of the Greenland ice sheet, J. Glaciol., 54, 567-578, 2008.

Chen, J. L., Wilson, C. R., and Tapley, B. D.: Interannual variability of Greenland ice losses from satellite gravimetry, J. Geophys. Res., 116, 1-11, doi:10.1029/2010JB007789, 2011.

Colgan, W., Rajaram, H., Anderson, R. S., Steffen, K., Phillips, T., Joughin, I. R., Zwally, H. J., and Abdalati, W.: The annual glaciohydrology cycle in the ablation zone of the Greenland ice sheet: Part 1. Hydrology model, J. Glaciol., 57, 697-709, doi:10.3189/002214311797409668, 2011.

Cowton, T., Nienow, P., Sole, A., Wadham, J., Lis, G., Bartholomew, I., Mair, D. W. F., and Chandler, D. M.: Evolution of drainage system morphology at a land-terminating Greenland outlet glacier, J. Geophys. Res., 118, 1-13, doi:10.1029/2012JF002540, 2012.

Cuffey, K. and Paterson, W. S. B.: The Physics of Glaciers, 4th Edn., Elsevier Inc., Burlington and Oxford, 2010.

Dingman, S.: Physical Hydrology, 2nd Edition, Prentice Hall, Upper Saddle River, New Jersey, 2002.

Doyle, S. H., Hubbard, A. L., Dow, C. F., Jones, G. A., Fitzpatrick, A., Gusmeroli, A., Kulessa, B., Lindback, K., Pettersson, R., and Box, J. E.: Ice tectonic deformation during the rapid in situ drainage of a supraglacial lake on the Greenland Ice Sheet, The Cryosphere, 7, 129-140, doi:10.5194/tc-7-129-2013, 2013.

Ettema, J., Van den Broeke, M. R., Van Meijgaard, E., Van de Berg, W. J., Bamber, J. L., Box, J. E., and Bales, R. C.: Higher surface mass balance of the Greenland ice sheet revealed by high-resolution climate modeling, Geophys. Res. Lett., 36, 4-8, doi:10.1029/2009GL038110, 2009.

Fausto, R. S., Ahlstrøm, A. P., Van As, D., Johnsen, J., Langen, P. L., and Steffen, K.: Improving surface boundary conditions with focus on coupling snow densification and meltwater retention in large-scale ice-sheet models of Greenland, Environ. Sci., 55, 869-878, 2009.

Fettweis, X.: Reconstruction of the 1979-2006 Greenland ice sheet surface mass balance using the regional climate model MAR, The Cryosphere, 1, 21-40, doi:10.5194/tc-1-21-2007, 2007.

Fountain, A. G. and Walder, J.: Water flow through temperate glaciers, Rev. Geophys., 36, 299-328, 1998.

Greuell, W. and Konzelmann, T.: Numerical modelling of the energy balance and the englacial temperature of the Greenland Ice Sheet. Calculations for the ETH-Camp location (West Greenland, 1155 m a.s.1.), Global Planet. Change, 9, 91-114, 1994.

Hagen, J. O., Kohler, J., Melvold, K., and Winther, J.: Glaciers in Svalbard: mass balance, runoff and freshwater flux, Polar Res. 22, 145-159, 2003.

Hall, D. K., Comiso, J. C., DiGirolamo, N. E., Shuman, C. a., Box, J. E., and Koenig, L. S.: Variability in the Surface Temperature and Melt Extent of the Greenland Ice Sheet from MODIS, Geophys, Res. Lett., 40, 2114-2120, doi:10.1002/grl.50240, 2013.

Hanna, E., Huybrechts, P., Steffen, K., Cappelen, J., Huff, R., Shuman, C. a., Irvine-Fynn, T. D. L., Wise, S., and Griffiths, M.: Increased runoff from melt from the Greenland Ice Sheet: A response to global warming, J. Climate, 21, 331-341, doi:10.1175/2007JCLI1964.1, 2008.

Harig, C. and Simons, F. J.: Mapping Greenland' s mass loss in space and time, 2012, 24-27, doi:10.1073/pnas.1206785109, 2012.

Harper, J. T. and Humphrey, N. F.: Borehole video analysis of a temperate glacier' englacial and subglacial structure: Implications for glacier flow models, Geology, 23, 901, doi:10.1130/00917613(1995)023<0901:BVAOAT>2.3.CO;2, 1995.

Harper, J., Humphrey, N., Pfeffer, W. T., Brown, J., and Fettweis, X.: Greenland ice-sheet contribution to sea-level rise buffered by meltwater storage in firn, Nature, 491, 240-243, doi:10.1038/nature11566, 2012.

Hodson, A. J.: Multi-year water and surface energy budget of a high-latitude polythermal glacier: evidence for overwinter water storage in a dynamic subglacial reservoir, Ann. Glaciol., 42, 42-46, 2005.

Humphrey, N. F., Harper, J. T., and Pfeffer, W. T.: Thermal tracking of meltwater retention in Greenland's accumulation area, J. Geophys. Res., 117, 1-11, doi:10.1029/2011JF002083, 2012.

Irvine-Fynn, T. D. L., Hodson, A. J., Moorman, B. J., Vatne, G., and Hubbard, A. L.: Polythermal Glacier Hydrology: A Review, Rev. Geophys., 49, RG4002, doi:10.1029/2010RG000350, 2011.

Janssens, I. and Huybrechts, P.: The treatment of meltwater retention in mass-balance parameterizations of the Greenland ice sheet, Ann. Glaciol., 31, 133-140, 2000.

Jansson, P., Hock, R., and Schneider, T.: The concept of glacier storage: a review, J. Hydrol., 282, 116-129, doi:10.1016/S00221694(03)00258-0, 2003.

Krabill, W., Hanna, E., Huybrechts, P., Abdalati, W., Cappelen, J., Csatho, B., Frederick, E., Manizade, S., Martin, C., Sonntag, J., Swift, R., Thomas, R. H., and Yungel, J.: Greenland Ice Sheet: Increased coastal thinning, Geophys. Res. Lett., 31, L24402, doi:10.1029/2004GL021533, 2004.

Lewis, S. M. S. and Smith, L. C.: Hydrologic drainage of the Greenland Ice Sheet, Hydrol. Process., 23, 2004-2011, doi:10.1002/hyp.7343, 2009.

Luthcke, S. B., Zwally, H. J., Abdalati, W., Rowlands, D. D., Ray, R. D., Nerem, R. S., Lemoine, F. G., McCarthy, J. J., and Chinn, D. S.: Recent Greenland ice mass loss by drainage system from satellite gravity observations., Science (New York, N.Y.), 314, 1286-1289, doi:10.1126/science.1130776, 2006.

Mathews, W. H.: Discharge of a glacial stream, International Association of Hydrological Sciences, 63, 290-300, 1963.

Mernild, S. H. and Hasholt, B.: Observed runoff, jokulhlaups and suspended sediment load from the Greenland ice sheet at Kangerlussuaq, West Greenland, 2007 and 2008, J. Glaciol., 55, 855858, doi:10.3189/002214309790152465, 2009.

Mernild, S. H. and Liston, G. E.: Greenland Freshwater Runoff. Part II: Distribution and Trends, 1960-2010, J. Climate, 25, 60156035, doi:10.1175/JCLI-D-11-00592.1, 2012.

Mernild, S. H., Liston, G. E., Steffen, K., van den Broeke, M., and Hasholt, B.: Runoff and mass-balance simulations from the Greenland Ice Sheet at Kangerlussuaq (Søndre Strømfjord) in a 
30-year perspective, 1979-2008, The Cryosphere, 4, 231-242, doi:10.5194/tc-4-231-2010, 2010a.

Mernild, S. H., Liston, G. E., Hiemstra, C. A., Steffen, K., Hanna, E., and Christensen, J. H.: Greenland Ice Sheet surface mass-balance modelling and freshwater flux for 2007, and in a 1995-2007 perspective, Hydrol. Process., 23, 2470-2484, doi:10.1002/hyp.7354, 2009.

Mernild, S. H. S. H., Liston, G. E., Hiemstra, C. A., and Christensen, J. H.: Greenland Ice Sheet Surface Mass-Balance Modeling in a 131-Yr Perspective, 1950-2080, J. Hydrometeorol., 11, 3-25, doi:10.1175/2009JHM1140.1, 2010b.

Mote, T. L.: Greenland surface melt trends 1973-2007: Evidence of a large increase in 2007, Geophys. Res. Lett., 34, L22507, doi:10.1029/2007GL031976, 2007.

National Climatic Data Center: Global Surface Summary of day data, version 7, 2011.

Nghiem, S. V., Hall, D. K., Mote, T. L., Tedesco, M., Albert, M. R., Keegan, K., Shuman, C. A., DiGirolamo, N. E., and Neumann, G.: The extreme melt across the Greenland ice sheet in 2012, Geophys. Res. Lett., 39, 6-11, doi:10.1029/2012GL053611, 2012.

Pelletier, P.: A review of techniques used by Canada and other Northern countries for measurement and computation of streamflow under ice condtions, Nord. Hydrol., 21, 317-340, 1990.

Pfeffer, W. T., Harper, J. T., and O'Neel, S.: Kinematic constraints on glacier contributions to 21st-century sea-level rise., Science (New York, N.Y.), 321(5894), 1340-1343, doi:10.1126/science.1159099, 2008.

Phillips, T., Rajaram, H., and Steffen, K.: Cryo-hydrologic warming: A potential mechanism for rapid thermal response of ice sheets, Geophys. Res. Lett., 37, L20503, doi:10.1029/2010GL044397, 2010.

Phillips, T., Colgan, W., Rajaram, H., and Steffen, K.: Evaluation of cryo-hydrologic warming as an explanation for increased ice velocities near the equilibrium line, Southwest Greenland, J. Geophys. Res., in press, doi:10.1002/jgrf.20079, 2013.

Pritchard, H. D., Arthern, R. J., Vaughan, D. G., and Edwards, L. A.: Extensive dynamic thinning on the margins of the Greenland and Antarctic ice sheets, Nature, 461, 971-975, doi:10.1038/nature08471, 2009.

Ramillien, G., Lombard, A., Cazenave, A., Ivins, E., Llubes, M., Remy, F., and Biancale, R.: Interannual variations of the mass balance of the Antarctica and Greenland ice sheets from GRACE, Global Planet. Change, 53, 198-208, doi:10.1016/j.gloplacha.2006.06.003, 2006.

Rantz, S. E. E.: Measurement and computation of streamflow: Volume 1, measurement of stage and discharge; Volume 2. Computation of Discharge, US Geological Survey water-supply paper 2175, 631, Washington, 1982.

Reeh, N.: Parameterization of Melt Rate and Surfaee Surface Temperature on the Greenland lee Ice Sheet, Polarforschung, 53, 113-128, 1991.

Rennermalm, A. K., Smith, L. C., Chu, V. W., Forster, R. R., Box, J. E., and Hagedorn, B.: Proglacial river stage, discharge, and temperature datasets from the Akuliarusiarsuup Kuua River northern tributary, Southwest Greenland, 2008-2011, Earth Syst. Sci. Data, 4, 1-12, doi:10.5194/essd-4-1-2012, 2012.

Rennermalm, A. K., Moustafa, S. E., Mioduszewski, J., Chu, V. W., Forster, R. R., Hagedorn, B., Harper, J. T., Mote, T. L.,
Robinson, D. A., Shuman, C. A., Smith, L. C., and Tedesco, M.: Understanding Greenland ice sheet hydrology using an integrated multi-scale approach, Environ. Res. Lett., 8, 015017, doi:10.1088/1748-9326/8/1/015017, 2013.

Rignot, E., Box, J. E., Burgess, E. W., and Hanna, E.: Mass balance of the Greenland ice sheet from 1958 to 2007, Geophys. Res. Lett., 35, L20502, doi:10.1029/2008GL035417, 2008.

Rignot, E., Velicogna, I., Van den Broeke, M. R., Monaghan, A., and Lenaerts, J.: Acceleration of the contribution of the Greenland and Antarctic ice sheets to sea level rise, Geophys. Res. Lett., 38, L05503, doi:10.1029/2011GL046583, 2011.

Russell, A. J.: Jökulhlaup (ice-dammed lake outburst flood) impact within a valley-confined sandur subject to backwater conditions, Kangerlussuaq, West Greenland, Sediment. Geol., 215, 33-49, doi:10.1016/j.sedgeo.2008.06.011, 2009.

Russell, A. J., Carrivick, J. L., Ingeman-nielsen, T., Yde, J. C., and Williams, M.: A new cycle of Jokulhlaups at Russell Glacier, Kangerlussuaq, West Greenland, J. Glaciol., 57, 238-246, 2011.

Schoof, C.: Ice-sheet acceleration driven by melt supply variability, Nature, 468, 803-806, doi:10.1038/nature09618, 2010.

Selmes, N., Murray, T., and James, T. D.: Fast draining lakes on the Greenland Ice Sheet, Geophys. Res. Lett., 38, 1-5, doi:10.1029/2011GL047872, 2011.

Selmes, N., Murray, T., and James, T. D.: Characterizing supraglacial lake drainage and freezing on the Greenland Ice Sheet, The Cryosphere Discuss., 7, 475-505, doi:10.5194/tcd-7475-2013, 2013.

Shepherd, A., Ivins, E. R., Geruo, A., Barletta, V. R., Bentley, M. J., Bettadpur, S., Briggs, K. H., Bromwich, D. H., Forsberg, R., Galin, N., Horwath, M., Jacobs, S., Joughin, I. R., King, M. A., Lenaerts, J. T. M., Li, J., Ligtenberg, S. R. M., Luckman, A., Luthcke, S. B., McMillan, M., Meister, R., Milne, G., Mouginot, J., Muir, A., Nicolas, J. P., Paden, J., Payne, A. J., Pritchard, H., Rignot, E., Rott, H., Sorensen, L. S., Scambos, T. A., Scheuchl, B., Schrama, E. J. O., Smith, B., Sundal, A. V., van Angelen, J. H., van de Berg, W. J., van den Broeke, M. R., Vaughan, D. G., Velicogna, I., Wahr, J., Whitehouse, P. L., Wingham, D. J., Yi, D., Young, D., and Zwally, H. J.: A Reconciled Estimate of Ice-Sheet Mass Balance, Science, 338, 1183-1189, doi:10.1126/science.1228102, 2012.

Shreve, R. L.: Movement of Water in Glaciers, J. Glaciol., 11, 205 214, 1972.

Stenborg, T.: Problems Concerning Winter run-off from Glaciers, Geogr. Ann. A, 47, 141-184, 1965.

Sundal, A. V., Shepherd, A., Nienow, P. W., Hanna, E., Palmer, S., and Huybrechts, P.: Evolution of supra-glacial lakes across the Greenland Ice Sheet, Remote Sens. Environ., 113, 2164-2171, doi:10.1016/j.rse.2009.05.018, 2009.

Sundal, A. V., Shepherd, A., Nienow, P. W., Hanna, E., Palmer, S., and Huybrechts, P.: Melt-induced speed-up of Greenland ice sheet offset by efficient subglacial drainage, Nature, 469, 521524, doi:10.1038/nature09740, 2011.

Tedesco, M.: Snowmelt detection over the Greenland ice sheet from SSM/I brightness temperature daily variations, Geophys. Res. Lett., 34, L02504, doi:10.1029/2006GL028466, 2007.

Van As, D.: Warming, glacier melt and surface energy budget from weather station observations in the Melville Bay region of northwest Greenland, J. Glaciol., 57, 208-220, doi:10.3189/002214311796405898, 2011. 
Van As, D., Fausto, R. S., Ahlstrøm, A. P., Andersen, S. B., Andersen, M. L., Citterio, M., Edelvang, K., Gravesen, P., Machguth, H., Nick, F. M., Nielsen, S., and Weidick, A.: Programme for Monitoring of the Greenland Ice Sheet ( PROMICE ): first temperature and ablation records, Geol. Surv. Den. Greenl., 23, 7376, 2011.

Van As, D., Hubbard, A. L., Hasholt, B., Mikkelsen, A. B., van den Broeke, M. R., and Fausto, R. S.: Large surface meltwater discharge from the Kangerlussuaq sector of the Greenland ice sheet during the record-warm year 2010 explained by detailed energy balance observations, The Cryosphere, 6, 199-209, doi:10.5194/tc-6-199-2012, 2012.

Van de Wal, R. S. W., Greuell, W., Van den Broeke, M. R., Reijmer, C., and Oerlemans, J.: Surface mass-balance observations and automatic weather station data along a transect near Kangerlussuaq, West Greenland, Ann. Glaciol., 42, 311-316, 2005.

Van de Wal, R. S. W., Boot, W., Smeets, C. J. P. P., Snellen, H., Van den Broeke, M. R., and Oerlemans, J.: Twenty-one years of mass balance observations along the K-transect, West Greenland, Earth System Science Data, 4, 31-35, doi:10.5194/essd-431-2012, 2012.

Van den Broeke, M., Smeets, P., Ettema, J., van der Veen, C., van de Wal, R., and Oerlemans, J.: Partitioning of melt energy and meltwater fluxes in the ablation zone of the west Greenland ice sheet, The Cryosphere, 2, 179-189, doi:10.5194/tc-2-179-2008, 2008.

Van den Broeke, M. R., Bamber, J. L., Ettema, J., Rignot, E., Schrama, E., Van de Berg, W. J., Van Meijgaard, E., Velicogna, I., and Wouters, B.: Partitioning Recent Greenland Mass Loss, Science, 326, 984-986, doi:10.1126/science.1178176, 2009a.
Van den Broeke, M. R., Smeets, P., and Ettema, J.: Surface layer climate and turbulent exchange in the ablation zone of the west Greenland ice sheet, Int. J. Climatol., 2323, 2309-2323, doi:10.1002/joc.1815, 2009b.

Van den Broeke, M. R., Smeets, C. J. P. P., and van de Wal, R. S. W.: The seasonal cycle and interannual variability of surface energy balance and melt in the ablation zone of the west Greenland ice sheet, The Cryosphere, 5, 377-390, doi:10.5194/tc-5-377-2011, 2011.

Velicogna, I. and Wahr, J.: Greenland mass balance from GRACE, Geophys. Res. Lett., 32, L18505, doi:10.1029/2005GL023955, 2005.

Vernon, C. L., Bamber, J. L., Box, J. E., van den Broeke, M. R., Fettweis, X., Hanna, E., and Huybrechts, P.: Surface mass balance model intercomparison for the Greenland ice sheet, The Cryosphere, 7, 599-614, doi:10.5194/tc-7-599-2013, 2013.

Wadham, J.: Hydrochemistry of meltwaters draining a polythermalbased, high-Arctic glacier, south Svalbard: II. Winter and early Spring, Hydrol. Process., 14, 1767-1786, 2000.

Wadham, J. L., Hodgkins, R., Cooper, R. J., and Tranter, M.: Evidence for seasonal subglacial outburst events at a polythermal glacier, Finsterwalderbreen, Svalbard, Hydrol. Process., 15, 2259-2280, doi:10.1002/hyp.178, 2001.

WMO: Manual on stream gauging Volume 1: Fieldwork, WMONo. 1044, WMO-No. 10., World Meteorological Organization (WMO), Geneva, Switzerland, 2010a.

WMO: Manual on Stream Gauging, Volume II - Computation of Discharge, WMO-No. 1044, World Meteorological Organization (WMO), Geneva, Switzerland, 2010b. 